\title{
Online Purchase Behaviour of Food Product During Covid-19 Pandemic: a Study on Consumer of Bedukmutu Marketplace
}

\author{
Heri Akhmadi ${ }^{1,}{ }^{*}$, Zahra Fuadia Qurrotu Aini ${ }^{1}$, Aprila Saffana ${ }^{1}$ and Dedi Runanto ${ }^{2}$ \\ ${ }^{1}$ Department of Agribusiness, Universitas Muhammadiyah Yogyakarta, Indonesia \\ ${ }^{2}$ Department of Management, Universitas Muhammadiyah Purworejo, Indonesia
}

\begin{abstract}
Covid-19 pandemic has affected various aspects of life, one of which is consumer behaviour in purchasing food products. This study aims to examine online purchase behaviour of food products of Bedukmutu online marketplace consumers during the Covid-19 pandemic. A 5-point Likert scale, Rank Spearman correlation and multiple linear regression were used to explore purchasing behaviour, factors that are correlated with and influence consumer purchasing behaviour of food products during the pandemic. The results showed that there was a slightly increase in the monthly purchasing activity of food products during the pandemic which was dominated by cooking oil and beverage products with an average purchase value of IDR 250,000 to IDR 500,000. Furthermore, compatibility and usability variable are proven to have a strong correlation and have a positive and significant effect on consumer purchase intention of food products during the Covid-19 pandemic.
\end{abstract}

\section{Introduction}

Corona Virus Disease (Covid-19) has been designated by World Health Organization (WHO) as a global disaster [1] that hit the majority of countries or is called a pandemic [2]. The determination of the status of this pandemic is certainly a sign that this health crisis has become so severe that it is not only threatens human health, but also has an effect on other aspects of life.

The impact of the Covid-19 outbreak on the health aspect is quite clear, WHO data as of August 2021 stated that more than 207 million people have been confirmed positive for this disease and have killed more than 4.36 million people from 216 countries/regions that reported cases [3]. In addition to the health impact, the other impact that is most likely to be felt is the economic sector. When people are restricted to work or travel in order to prevent transmission, that is when the economy stops.

However, there is always a blessing behind the calamity. Although almost all sectors of life have been affected by this pandemic [4], some sectors have experienced an increase in performance [5]. While the tourism, aviation, trade and sports sectors experienced a sharp decline since people had to stay at home, the online sales (e-commerce), health, and food

${ }^{*}$ Corresponding author: heriakhmadi@umy.ac.id 
delivery service sectors experienced a significant increase [6]. The agricultural sector itself, although affected in terms of disrupted supply chain, can still grow if it is able to utilize and switch to online services [7] because after all, food is still needed even though humans are at home.

The increase in sales of food products online even though in the midst of pandemic is interesting to explore further. Apart from this being a reverse phenomenon during a sluggish economy, this is may also inseparable from the development of information and communitation technology (ICT). The pandemic seems to encourage the stronger use of information technology in online trading [8].

The rapid growth of internet users and the increasing telecommunication infrastructure are increasingly supporting this phenomenon. Increasingly affordable technology devices have also contributed to this development. Based on data from the Association of Indonesian Internet Service Providers (APJII) in 2020, it shows that $73.7 \%$ of Indonesia's population or 196.7 million people are active internet users [9]. The latest data in February 2021 recorded that 202.6 million Indonesians were active internet users [10].

Along with the increasing use of the internet, the purpose of ICT use is also increasingly diverse. Apart from being a communication tool and medium for sending messages, seeking information (search engines), the internet is also growing to support business [11]. There are various uses of the internet in business, ranging from searching for product information and buying and selling, online payments and transactions and various other purposes [12].

The use of the internet in business has basically grown from the beginning of the emergence of the internet. The Covid-19 pandemic which is forcing people to stay at home and run businesses online has made the internet more important in business. There are various platforms used in business using the internet, ranging from the use of business social media, online shopping and marketplaces. Marketplace is one of the platforms that is widely used in online trading of food products.

Bedukmutu is an online marketplace developed by the Universitas Muhammadiyah Yogyakarta (UMY) Indonesia, with the main objective of empowering Muhammadiyah members in UMY [13]. Since its launch in 2017, Bedukmutu has grown rapidly. From the transaction turnover, only IDR 1,336,000 in July 2017 increased to IDR 730,349,583, - in March 2018 [14].

The increasing sales and the role of the Bedukmutu marketplace is an interesting trend considering the large economic potential of Muhammadiyah members. Previous research related to the Bedukmutu marketplace is more focused on the perception of product variations [14] and business models [12], there is no research that analyzes Bedukmutu consumer's purchasing behavior, especially during a pandemic. Therefore, this study aims to determine the online purchasing behavior of food products on Bedukmutu marketplace, especially during the Covid-19 pandemic.

\section{Methodology}

This study employed a descriptive method by conducting survey on March-April 2021 with Bedukmutu consumers. The descriptive method was chosen because it is a method for examining the status of a group, object, condition [15], situation or event in the present to obtain a systematic and accurate description of facts and phenomena [16,17].

Bedukmutu was chosen because it is an online marketing platform developed by Universitas Muhammadiyah Yogyakarta which is one of the higher education institutions under Muhammadiyah, one of the biggest Islamic community organizations with millions of members throughout Indonesia [18]. With the massive number of its members, economic activities of Muhammadiyah members is interesting. 
Respondents in this study were lecturers and permanent employees of Universitas Muhammadiyah Yogyakarta who were taken randomly from all the populations using proportional random sampling method. Based on data from the Bureau of Human Resources (BSDM) of UMY, the number of lecturers and permanent employees of Universitas Muhammadiyah Yogyakarta is 831 people [19]. From the population, samples were taken randomly and proportionally from each bureau and faculty at UMY. Based on the questionnaire distributed online, there were 104 consumers who responded and met the requirements to become respondents.

Primary data from respondents was obtained by distributing questionnaires using Google form platform which were distributed online via email and WhatsApp messaging services. The purchasing behavior of food products is measured using a 5-point Likert Scale for further analysis descriptively using the average score of each variable. There are four variables that are used to measure the buying behavior of food products during a pandemic (from March 2020 to January 2021), namely community relation variables, website interfaces, compatibility and usability variables. The relationship of the four variables with purchasing behavior was measured using Spearman Rank correlation analysis, while the influence of the variables was examined using multiple linear regression analysis.

\section{Result and Discussion}

\subsection{Bedukmutu food product consumer profile}

Respondents of this study were consumers of Bedukmutu food products consisting of lecturers and permanent employees of the Universitas Muhammadiyah Yogyakarta (UMY). Based on the data obtained, the characteristics of consumer respondents are arranged. There are five variables used to describe the demographic of the Bedukmutu consumers. The variables used are gender, age, education level, monthly income (take home pay) and number of dependents. The detail of demographic of Bedukmutu food product consumers during the Covid-19 pandemic was presented in Table 1.

Table 1 shows that the majority of Bedukmutu food products consumers during the Covid-19 pandemic were male, namely 67 people or $64.4 \%$, while the remaining 37 people $(35.6 \%)$ were female. This is in line with data from the Human Resources Bureau of the Universitas Muhammadiyah Yogyakarta in 2020, where the majority of employees (lecturers and permanent employees) of UMY (522 people out of 831) are male [19]. Food products are usually consumed to meet household needs. And in general, the responsibility for fulfilling household needs is the duty of men as the head of the family.

Furthermore, related to the age variable, to better understand consumer behavior, especially related to online purchases, this study divides respondents into three age groups based on theory of generation. The three age groups are respondents aged 24 to 39 years who are included in the millennial generation category. Furthermore, those aged 40 to 60 years are categorized as Generation X, and finally respondents aged 61 to 78 years are included in the baby boomers category [20].

Based on age variable, the majority of respondents (60 people or $57.7 \%$ ) aged between 40 to 60 years or categorized as Generation X. Next with the proportion that is not much different is the millennial generation which covers $40.4 \%$ of the total respondents. While the rest $(1.9 \%)$ were the Baby Boomers generation. This data shows that Generation $\mathrm{X}$ and millennials were the dominant consumers of Bedukmutu. In the behavior of purchasing food products, Generation X and Generation Y (millennials) are known as generations who are aware of healthy and environmentally friendly food products [21]. 
Table 1. Respondent demographic profile $(\mathrm{N}=104)$

\begin{tabular}{|c|c|c|c|c|}
\hline \multirow{2}{*}{ No } & \multirow{2}{*}{ Variable } & \multirow{2}{*}{ Range } & \multicolumn{2}{|c|}{ Respondent } \\
\hline & & & Number & $\%$ \\
\hline \multirow[t]{2}{*}{1} & Gender & Male & 67 & 64.4 \\
\hline & & Female & 37 & 35.6 \\
\hline \multirow[t]{3}{*}{2} & Age (Year) & 24 - 39 (Millennial) & 42 & 40.4 \\
\hline & & 40 - 60 (Generation X) & 60 & 57.7 \\
\hline & & 61- 78 (Baby Boomers) & 2 & 1.9 \\
\hline \multirow[t]{5}{*}{3} & Education & Senior High School & 18 & 17.3 \\
\hline & & Diploma & 3 & 2.9 \\
\hline & & Undergraduate & 13 & 12.5 \\
\hline & & Master & 51 & 49.0 \\
\hline & & Doctoral & 19 & 18.3 \\
\hline \multirow[t]{4}{*}{4} & Take home pay (IDR/month) & $<5,000,000$ & 52 & 50.0 \\
\hline & & $5,000,000-\leq 10,000,000$ & 41 & 39.4 \\
\hline & & $>10,000,000-\leq 15,000,000$ & 8 & 7.7 \\
\hline & & $>15,000,000$ & 3 & 2.9 \\
\hline \multirow[t]{3}{*}{5} & Family member & $0-2$ & 47 & 45.2 \\
\hline & & $3-4$ & 47 & 45.2 \\
\hline & & $\geq 5$ & 10 & 9.6 \\
\hline
\end{tabular}

Furthermore, with regard to educational background, respondents with a master's degree were the majority consumers of Bedukmutu, amounting to 51 people or $49 \%$ of the total population. Meanwhile, there were 19 people $(18.3 \%)$ with doctoral degrees and 13 people with bachelor degrees $(12.5 \%)$ and the rest 21 respondent were hold Diploma or and high school educational background. Previous studies show that education level has an influence on online purchase behavior [22,23].

Interm of income, the amount of income or average monthly take home pay as presented in Table 1 shows that 52 people or $50 \%$ of the total respondents, have monthly income of IDR 5,000,000. Other respondents as many as 41 people or $39.4 \%$ have an income between IDR $5,000,000.00$ and $10,000,000.00$. Only 8 people or $7.7 \%$ for respondents who have an income from IDR 10,000,000.00 to IDR 15,000,000.00 per month. Meanwhile, consumers with the highest income, which is above IDR 15,000,000.00 per month only 3 people or $2.90 \%$ of the total respondents. The relationship between income and online shopping behavior is generally related to the reasons people shop. People with high incomes tend to choose online shopping to save time, whereas people with low incomes tend to save money when shopping online [24].

The last consumer demographic aspect is the number family members. Family has an influence on a consumer's decision to purchase or not to purchase a product [25]. This study shows that the majority of Bedukmutu consumers, namely 47 people or $45.2 \%$, have 0 to 2 family dependents, same portion with respondents who have 3 to 4 family members. While the rest, as many as 10 people or $9.60 \%$, have family dependents of more than or equal to 5 people.

\subsection{Food product purchase behavior on bedukmutu}

The activity of purchasing food products on Bedukmutu marketplace during the Covid-19 pandemic could provide an initial picture of how Bedukmutu's consumer purchasing behavior during the pandemic. There were several things that were extracted from this purchasing activity including: 


\subsubsection{Food Product Purchase Behavior During the Pandemic}

Food products purchasing activity on Bedukmutu marketplace during the Covid-19 pandemic could provide an initial picture of how Bedukmutu's consumer purchase behavior during the pandemic. There were several things that extracted from this purchasing activity including the frequency of purchases before and after the pandemic, the value of monthly purchases (in Rupiah/IDR) and the types of food products purchased during the pandemic. More details regarding the activity of purchasing food products during the pandemic are presented in Table 2 .

Table 2. Food product purchase activities before and during the pandemic

\begin{tabular}{|c|c|c|}
\hline Food Product Purchase Activities & Number & $\%$ \\
\hline \multicolumn{3}{|l|}{ Before the Pandemic (Before March 2020) } \\
\hline Never & 2 & 1.90 \\
\hline Once in a year & 55 & 52.90 \\
\hline Once in a month & 43 & 41.30 \\
\hline Once in a week & 4 & 3.90 \\
\hline Everyday & 0 & 0 \\
\hline \multicolumn{3}{|l|}{ During the Pandemic (March 2020 - March 2021) } \\
\hline Never & 0 & 0 \\
\hline Once in a year & 54 & 51.90 \\
\hline Once in a month & 47 & 45.20 \\
\hline Once in a week & 3 & 2.90 \\
\hline Everyday & 0 & 0 \\
\hline \multicolumn{3}{|l|}{ Food Product Category } \\
\hline Oil, margarine & 71 & 22.7 \\
\hline Coffee, tea and beverage products & 61 & 19.5 \\
\hline $\begin{array}{l}\text { Cereal products and their derivatives (rice, corn, } \\
\text { cereals, flour) }\end{array}$ & 43 & 13.7 \\
\hline Meat and processed meat & 33 & 10.5 \\
\hline Dairy product & 23 & 7.35 \\
\hline Bread and bakery products & 23 & 7.3 \\
\hline Fish and processed fish & 20 & 6.4 \\
\hline Spices, salt and cooking spices & 14 & 4.5 \\
\hline Chocolate, candy & 10 & 3.2 \\
\hline Other & 9 & 2.9 \\
\hline Fruit and vegetables & 5 & 1.6 \\
\hline Baby products (formula milk, complementary foods) & 1 & 0.35 \\
\hline \multicolumn{3}{|l|}{ Average Spending During Pandemic (IDR) } \\
\hline$\leq 100,000$ & 13 & 12.50 \\
\hline$>100,000-250,000$ & 26 & 25.00 \\
\hline$>250,000-500,000$ & 53 & 51.00 \\
\hline$>500,000-1,000,000$ & 8 & 7.70 \\
\hline$>1,000,000$ & 4 & 3.80 \\
\hline
\end{tabular}

Table 2 shows that before the Covid-19 pandemic (before March 2020), the majority of purchasing activities were carried out occasionally in a year $(52.9 \%)$ and occasionally in a month $(41.3 \%)$. Data before the pandemic also stated that there were very few people who did not buy food products at all, ( 2 consumers or $1.9 \%)$. During the pandemic, this pattern is almost the same, except that there was a slight increase in monthly purchasing activity to 
$45.2 \%$ from the previous period of $41.3 \%$. In addition, during the pandemic there is no consumer who does not make a purchase. These results confirm previous studies where there was an increase in the purchase of food products during the pandemic [26].

Furthermore, regarding the types of food products purchased by consumers through Bedukmutu marketplace during the Covid-19 pandemic (from March 2020 to March 2021), this research refers to 12 categories of food products based on Food Category System (FCS) of the Codex General Standards for Food Additives (GSFA) of Food and Agriculture Organization (FAO) of the United Nations [27]. Respondents are allowed to choose more than one type of food product that has been purchased through Bedukmutu marketplace.

Based on Table 2, it can be seen that the most purchased of food products by respondents are oil and margarine where a total of 71 people or $22.70 \%$ of consumers stated that they had bought them during the pandemic. Meanwhile, the next most consumed type of food product is coffee, tea and beverage products with 61 consumers or $19.5 \%$ having bought it. While infant milk formula and complementary foods was the the least purchased of products during the pandemic, which was only one person or $0.35 \%$ of the total respondents. This study confirms previous research that oil products were among the most purchased by consumers during the pandemic [28]. Restriction activities during the pandemic that forced people to stay at home make them doing most all activities from home, including providing food or cooking for their family.

Finally, regarding the value of food product purchases during the pandemic, the majority of consumers (51\%) bought products between IDR 250,000 to 500,000. While the types of food products purchased during the pandemic were mostly food products in the form of oil and margarine by $68.3 \%$, beverage products by $58.7 \%$ and cereal products such as rice by $41.3 \%$.

\subsubsection{Relationship of Online Purchase Behavior and Variables That Influence It}

To understand more deeply about the activity of purchasing food products on the Bedukmutu marketplace during the Covid-19 pandemic, further analysis of the relationship between purchasing behavior and several variables were predicted to have relation i.e community relation, website interface, compatibility and usability. The results of the Spearman Rank correlation analysis between purchasing behavior and variables that are thought to have a relationship are presented in Table 3.

Table 3. Rank Spearman Correlation between online purchase behavior and variables that influence it

\begin{tabular}{|l|c|c|c|}
\hline \multicolumn{1}{|c|}{ Variabel } & Coefficient of Correlation & Sig. & Category \\
\hline Community Relation & 0.415 & 0.000 & Moderate \\
\hline Website interface & 0.500 & 0.000 & Moderate \\
\hline Compatibility & 0.622 & 0.000 & Strong \\
\hline Utility & 0.653 & 0.000 & Strong \\
\hline
\end{tabular}

Table 3 shows that community ties and website interface variables have a moderate and positive relationship with the food online purchase behavior. This is in line with previous research which stated that consumer who has community relation with sellers tend to purchase more [29] as well as the website interface variable which provide information to buyer has positive relation to online purchase intention [30].

Moreover, the compatibility and utility variables show a high and positive relationship with online purchase behavior of food products, with the coefficient of 0.622 and 0.653 and a confidence level of $99 \%$. This is also in accordance with the results of previous research 
which states that the compatibility or suitability variable has a relationship with consumer's online purchase interest through the marketplace [31].

\subsubsection{Factor That Influence Food Online Purchase Behavior During Pandemic}

In relation to the influence of community relation variables, website interfaces, compatibility and usability variables on food products purchase behavior of on Bedukmutu marketplace during the Covid-19 pandemic, the results are presented in Table 4. The multiple regression analysis of four variables examined in this study shows the R-squared value of 0.631 . This means that $63.1 \%$ of the variation in food products online purchase behavior of Bedukmutu were influenced by community relations, website interfaces, compatibility and utility variables. The remaining $37 \%$ was influenced by other variables.

Table 4. Factors that influence food online purchase behavior during pandemic

\begin{tabular}{|l|c|c|c|}
\hline \multicolumn{1}{|c|}{ Variable } & Coefficient & t-Statistic & Sig. \\
\hline (Constant) & -0.474 & -2.454 & $0.016^{*}$ \\
\hline Community Relation & 0.104 & 2.005 & $0.048^{*}$ \\
\hline Website interface & -0.105 & -2.036 & $0.044^{*}$ \\
\hline Compatibility & 0.290 & 5.063 & $0.000^{* *}$ \\
\hline Utility & 0.802 & 8.185 & $0.000^{* *}$ \\
\hline R-Squared & 0.631 & & $* *=$ Significant at 1\% \\
\hline Adjusted R-Squared & 0.616 & & $*$ Significant at 5\% \\
\hline Prob (F-statistic) & 0.000 & & \\
\hline F-statistic & 42.357 & & \\
\hline
\end{tabular}

Based on the regression results in Table 4, community relation variable proved to have a positive and significant effect on online purchase intention of food products with a regression coefficient of 0.104 . This means that if community ties are increased by one level, online purchase intention of food products through Bedukmutu marketplace will increase by 0.104 units. This is in accordance with the results of other studies where online purchasing decision making can be influenced by information obtained from organizations or social ties from which consumers come [32]. Furthermore, in the context of purchasing activities at Bedukmutu, one of the reasons for purchasing food products is the regulation for lecturers and employees within the framework of the UMY Employee Performance Indicator or so called Satuan Kinerja Pegawai (SKP) where the purchase of products and services on Bedukmutu marketplace is one of the performance indicators of UMY employees. Apart from that, the majority of the sellers in Bedukmutu are UMY lecturers and employees also, in other words, some buyers are also familiar with the sellers of their products. The existence of a friendship relationship can affect a person's purchasing interest [33].

The next variable is the website interface, the regression results show that this variable also significantly affects online purchase intention of food products with unexpected negative coefficient of -0.105 . This means that improving the quality of Bedukmutu's website interface actually decrease online purchase intention of food products. This negative result contradicts previous research which states that improving website quality could encourage consumers to purchase more [34,23].

Furthermore, the compatibility variable which in this study proved to have a significant and positive effect on purchase of food products at Bedukmutu marketplace with a coefficient of 0.290 . Compatibility in online purchases can be interpreted that purchasing of food products using online platform such as marketplace is in accordance with the consumers preferences on purchasing activities [35]. 
Finally, the usability variable shows a significant positive effect on online purchase intention with a regression coefficient of 0.802 . This means that every one level increase in utility of the Bedukmutu marketplace could increase online food purchase intention by 0.8 units. Perceived utility is the assumption from consumers that their online purchasing activities provide benefits and convenience in use [36]. Especially during pandemic, online purchasing platforms provide utilities in the form of security for consumers to conduct transactions without direct meetings, thereby reducing the danger of disease transmission [37].

\section{Conclusions}

Based on result and discussion, this study concluded that there was a slightly increase in the monthly purchasing activity of food products during the pandemic which was dominated by cooking oil and beverage products with an purchase value from IDR 250,000 to IDR 500,000 . Furthermore, compatibility and usability variable are proven to have a strong correlation and have a positive and significant effect on consumer purchase intention of food products during the Covid-19 pandemic.

This research contributes to providing an overview of the online purchasing behavior of food products during the pandemic, especially through the marketplace platform. However, there are limitations in this study, one of which is the limited number of respondents and limited data since Bedukmutu consumers are only UMY lecturers and employees. Future research can be expanded to other marketplaces so that the consumer coverage is wider.

This paper has been financially supported by the Institute of Research, Publication and Community Service, Universitas Muhammadiyah Yogyakarta. The authors thank the Department of Agribusiness research team who assisted the data collection process.

\section{References}

1. WHO, Coronavirus Dis. Pandemic (2020).

2. A. O. Herman, NEJM J. Watch (2020).

3. WHO, WHO Coronavirus Disease (COVID-19) Dashboard (2021).

4. W. J. McKibbin and R. Fernando, SSRN Electron. J. 19, 45 (2020).

5. J. E. Hobbs, Can. J. Agric. Econ. Can. d'agroeconomie 1 (2020).

6. Yuswohady, (2020).

7. M. M. Chandola, S. Kulkarni, and S. Tanwade, Turkish J. Physiother. Rehabil. 32, 9618 (2021).

8. K. Mouratidis and A. Papagiannakis, Sustain. Cities Soc. 74, 103182 (2021).

9. APJII, Penetrasi Dan Perilaku Pengguna Internet Indonesia 2020 (2020).

10. Statista, Stat. Res. Dep. (2021).

11. A. Sestino, M. I. Prete, L. Piper, and G. Guido, Technovation 98, 102173 (2020).

12. H. Akhmadi and S. Pratolo, in International Conference on Agribusiness and Rural Development (IConARD 2020) (2021), p. 02015.

13. S. Pratolo and Misbahulanwar, in Semin. Nas. Fak. Ekon. Univ. Muhammaadiyah Ponorogo (Ponorogo, 2018).

14. Jumarodin, A. Sutanto, and F. Adhilla, J. Manaj. Bisnis 10, 102 (2019).

15. H. Akhmadi, I. Shofiyati, and Sriyadi, in IOP Conference Series: Earth and 
Environmental Science,. (2021).

16. M. Nazir, Metode Penelitian, 9th ed. (Ghalia Indonesia, Jakarta, 2014).

17. A. F. Abadega, AGRARIS: Journal of Agribusiness and Rural Development Research. 7, 53 (2021).

18. A. M. Al-ansi, T. Sulistyaningsih, and R. Kartono, Open Access Libr. J. 6, 1 (2019).

19. BSDM UMY, Daftar Pegawai Aktif (Yogyakarta, 2020).

20. K. Magsamen-Conrad and J. M. Dillon, Comput. Human Behav. 112, 106456 (2020).

21. I. Kamenidou, A. Stavrianea, and E. Z. Bara, Sustain. 12, 1 (2020).

22. A. Dominici, F. Boncinelli, F. Gerini, and E. Marone, J. Retail. Consum. Serv. 60, 102473 (2021).

23. J. Hasanov and H. Khalid, Procedia Comput. Sci. 72, 382 (2015).

24. G. Punj, J. Bus. Res. 65, 634 (2012).

25. S. Kamalul Ariffin, T. Mohan, and Y. N. Goh, J. Res. Interact. Mark. 12, 309 (2018).

26. B. Celik, K. Ozden, and S. Dane, J. Res. Med. Dent. Sci. 8, 51 (2020).

27. FAO, Updat. up to 42nd Sess. Codex Aliment. Comm. (2019).

28. E. Sánchez-Sánchez, G. Ramírez-Vargas, Y. Avellaneda-López, J. I. Orellana-Pecino, E. García-Marín, and J. Díaz-Jimenez, Nutrients 12, 1 (2020).

29. R. Yang and T. Che, Comput. Human Behav. 110, 106376 (2020).

30. R. U. Oni, W. Sentanu, N. Valentinus, and P. A. Manaf, Int. J. Manag. 11, 158 (2020).

31. D. An, S. Ji, and I. U. Jan, Sustain. 13, 1 (2021).

32. L. Ma, X. Zhang, X. Ding, and G. Wang, J. Theor. Appl. Electron. Commer. Res. 16, 395 (2021).

33. S. Li, N. Cai, and Z. Yu, Multimed. Tools Appl. 79, 7649 (2020).

34. C. Alianto, H. Semuel, and S. Wijaya, Proc. 2nd Int. Conf. Bus. Manag. Technol. (ICONBMT 2020) 175, 275 (2021).

35. N. Peña-García, I. Gil-Saura, A. Rodríguez-Orejuela, and J. R. Siqueira-Junior, Heliyon 6, (2020).

36. J. Yin and X. Qiu, Sustain. 13, (2021).

37. M. S. A. Latip, F. T. Newaz, R. Ramasamy, S. A. Tumin, and I. Noh, Malaysian J.

Consum. Fam. Econ. 24, 261 (2020). 